\title{
Power at the expense of diffuse interests? The European Parliament as a legitimacy-seeking institution.
}

GREENWOOD, J. and ROEDERER-RYNNING, C. 
Power at the expense of diffuse interests?

The European Parliament as a legitimacy-seeking institution ${ }^{1}$

\title{
Justin Greenwood, Robert Gordon University \\ Christilla Roederer-Rynning, University of Southern Denmark
}

Keywords: European Parliament; legitimacy seeking; diffuse interests; NGOs. Word count: 8258

\begin{abstract}
Has the European Parliament (EP)'s acquisition of legislative powers diluted its traditional support for diffuse interests? This article considers the various arguments that challenge the EP's reputation as a champion of diffuse interests and advances an alternative interpretation grounded in the idea of the EP as a legitimacy seeking institution. These arguments are explored in light of EP strategies of public engagement. Whilst previous analyses have been centred on the EP itself, we broaden the empirical focus to examine patterns of diffuse interest engagement with the EP. We find variance in the way diffuse advocates engage with the EP, and identify a driver of differentiation among NGO advocates of diffuse interests organized at EU level. We draw on interviews with NGOs, representatives from EU political institutions, as well as data from the Transparency Register to assess NGO/EP interactions.
\end{abstract}

\footnotetext{
1 The authors gratefully acknowledge support from the ESRC grant Grant no: ES/NO18761/1: Democratic Legitimacy in the EU: Inside the 'Black Box of Informal Trilogues':, and are grateful for the comments of two anonymous referee.
} 
Accepted for publication in European Politics and Society, 2019

\section{Introduction}

The European Parliament (EP) was traditionally seen as a source of support for ambitious regulatory demands, making it a seemingly favourable venue for 'diffuse interests’ (Judge, 1992; Pollack, 1997; Kohler-Koch 1998; Watson and Shackleton, 2003). This perception has changed in recent years, as scholarly accounts have highlighted some problematic effects of the EP's growing legislative power. In an era where the EP lacked competencies it had been easy for it to support a range of popular causes, but its changing role has given rise to mixed accounts of the way it works with diffuse interests (Smith, 2008; Burns and Carter, 2010; Burns et al, 2013; Kurzer and Cooper, 2012; Rasmussen, 2012; Rasmussen, 2014). We examine whether and how the EP's acquisition of legislative powers has diluted its traditional support for diffuse interests. First, we synthesize recent arguments put forward in the literature under a broader political opportunity perspective. While rooted in different literatures, these arguments help us understand different pieces of the broader puzzle of the EP's role in championing diffuse interests. They draw our attention to key dimensions of the external environment of diffuse and organized advocates, which impact upon their involvement in the EU policy-making process. Second, we develop an alternative interpretation of the EP as a 'demoi-cratic' legitimacy seeking institution (Cheneval et al, 2015); while political opportunity arguments tend to view the EP as a utilityseeking institution, this interpretation emphasizes the normative bases of EP behaviour. A key insight underpinning this view is that, acting upon accepted standards of democratic representation, the EP will strive to seek institutional autonomy, among other things through the development of in-house knowledge, in order to continue to champion diffuse interests. It therefore provides a useful frame 
with which to revisit some of the claims about changes in the way in which the EP engages with diffuse interests.

Third, whereas most of the extant literature is EP-centred, we include an analysis of NGOs as organized advocates for diffuse interests, which an established literature in transnational decision making systems identify as systemic proxies for civil society interests (Steffek, 2013; Joachim \& Locher, 2009). Our analysis recognizes the distinction between: the EP adopting a mantle as entrepreneurial representative of diffuse interests which it perceives and defines; diffuse citizen mobilisation focused on the EP and facilitated largely by online means (Gehlen, 2006; Dür and Mateo, 2014); and NGOs acting as organized advocates of diffuse interests in a political system with limited popular engagement (Greenwood, 2017). Where issues are of high saliency, NGOs seek to enhance their reputation through aligning positions with their interpretation of public sentiment (Junk, 2015) Where they are successful in elevating issues to public salience, so the European Parliament tends to follow (Duer and Mateo, 2014; Rasmussen, 2014)..

\section{Power at the expense of diffuse interests—what are the claims?}

The recent literature provides a number of reasons to suppose that the EP's ‘champion’ role might have become diluted over time as a result of the legislative empowerment of the EP. In this section, we discuss the potential effects of the legislative empowerment of the EP for diffuse interests, using the concept of political opportunity structure. Developed in studies of the formation and consolidation of the nation-state (Tarrow, 1992) it has been used to capture changes in mobilization dynamics linked to the political process of European integration (Marks and McAdam 1996; Imig \& Tarrow, 2001). We distinguish four potential sources of increasing 
tensions between the EP and diffuse interests: (1) formal-institutional constraints relating to committee assignments under co-decision; (2) informal-institutional constraints relating to the embrace of informal trilogues in the practice of co-decision; (3) cultural-normative, relating to the evolution of EP preferences and selfunderstanding as a result of its legislative empowerment; and finally (4) materialinformational, relating to the EP's need for expertise in order to perform its legislative functions.

\section{Growing NGO-adverse committee assignment bias}

A first argument centred on institutional rules of the game highlights changes in the system of legislative referral in the EP. There have been claims that the introduction of the 'Hughes procedure' in the EP (2002)—involving the way in which legislative files are assigned to standing committees and relationships prescribed between them in cases of shared competence-constrained the role of committees with a record of championing diffuse interests (Smith 2008).

\section{Growth of NGO-adverse informal trilogues}

A second potential constraint for diffuse interests is the shift to early agreements concluded through informal inter-institutional negotiations ('trilogues'), and the distributional consequences this mechanism may carry for civil society interests. Trilogues are an informal institution bringing together the representatives of the EP, Council, and Commission in a secluded setting to conclude legislative agreements. Trilogues were not foreseen in the Treaties, which did not spell out the institutional mechanisms for resolving conflicts between the EP and Council under co-decision. They have nevertheless developed rapidly in the last decade (European Parliament 
2014a), to the extent that the General Court of the EU now recognises them as a regular part of the legislative process. Trilogues may hurt NGOs, and by extension diffuse interests, in several ways. First, trilogues are often characterized as 'black boxes’ making the EU policy process opaque (EurActiv, 2015, 2017; House of Lords, 2016) and unaccountable. Second, trilogues are also perceived as favouring those interests with superior resources, capable of developing access and monitoring the course of negotiations (Bunyan, 2007; International New York Times, 2014). Finally, in one interpretation, trilogues have been cast as disproportionately disadvantaging smaller parties in the EP because they get allocated fewer legislative files under the EP's points based system, thus diminishing the ability of left-leaning parties, in particular, to champion the cause of kindred diffuse interests is seen as notably diminished (Burns et al, 2013).

\section{Emergence of NGO-adverse legislative norms}

Two additional arguments are often advanced to link the shift to co-decision to a gradual rapprochement between the EP and business interests. First, there is an expectation that legislative empowerment has a moderating effect on the EP's preferences. When the EP has the power to enforce its position, it becomes more attentive to the political implications of its preferences and more sensitive to the political realities at hand. This is also a feature of studies contrasting generally strong public protection positions in a given policy field before the advent of co-decision with much more diluted positions taken afterwards (Burns \& Carter, 2010; Ripoll Servent and Mackenzie, 2011), and undertaken across a range of EP committees. These studies incorporate expectations of variance across EP committees according to the degree of familiarisation with co-decision powers, although Burns and Carter's 
Accepted for publication in European Politics and Society, 2019

analysis of positions adopted by one EP Committee up to the end of EP6 (2004-9), i.e. before the entry into force of the Lisbon Treaty, remains the only quantitative assessment to date. In a later section, we summarise insights from interviews drawing on the vast majority of EP committees.

\section{Increasing $\mathrm{EP}$ resource-dependency}

The other expectation is that legislative empowerment makes the EP more dependent on business interests and organizations for the provision of crucial policy information. This is because the information needs of a parliament with full legislative powers require that it expand its range of expert sources beyond advocates (Judge \& Earnshaw, 2011; Busby, 2012; Marshall, 2012); in turn, this is expected to give business interests greater political clout in the EP (Burson Marsteller, 2009; Coen, 2009; Dür and de Bièvre, 2007). Nonetheless, these latter expectations do not assimilate the distributional effects of regulatory proposals in which competitive interest group politics arise where costs and benefits divide the interests of capital, and from which political institutions can use to increase their autonomy.

Bouwen's classic study of business lobbying in the European Parliament in the period 2000-2001 was premised on a supposition that the driver of MEPs relationship with interest organisations at that time would be political knowledge ('encompassingness') rather than expert technical knowledge (Bouwen, 2004, see also Bouwen and Mccown, 2007)). As the EP's powers increased, so the expectation was generated that there would be a qualitative shift in the type of information which legislators would require. Here, advocates ('we want..') might be juxtaposed with professionalized interest organisations supplying sufficient information ('we want because..') to satisfy the needs of legislators. More recently, the focus has turned 
Accepted for publication in European Politics and Society, 2019

towards members of the EP secretariat and indirect lobbying by entrenched interests (including both Commission officials as well as by lobby organisations):

Using a mixture of deductive analysis together with survey data collected in the period 2007-2010, Marshall showed how committee secretariats developed their expertise proactively, but stealthily, 'filter[ing] and repackage[ing]' information gathered from their engagement with policy experts from the European Commission and from stakeholder interests as ‘independent expert advice’ (Marshall 2012: 1385). Sources of policy advice for MEPs forms part of any picture involving the establishment and diffusion of norms diffusion, examined in the following section.

\section{EElective affinities}

While these claims have now become established as the new conventional wisdom on the EP-NGO interactions, we argue that they underestimate the role of shared community norms in orienting EP actions with its environment. We propose here an alternative perspective, which emphasizes how the search for legitimacy has driven the EP to develop economic and social knowledge; and how, in turn, knowledgebuilding serves diffuse interests.

\section{The EP as a legitimacy-seeking institution}

Institution-building does not take place in a social vacuum: the emerging institutional nucleus must reckon with established forces in the surrounding community. ${ }^{2}$ This is a difficult situation as classic institutionalists foresaw. The would-be institution may not reflect the balance of power in the surrounding community; it lacks 'historical'

\footnotetext{
${ }^{2}$ This section partly draws on Roederer-Rynning (2018).
} 
legitimacy, and it may simply be 'unable to mobilize the community for action' (Selznick 1949, 260). From this perspective, the EP may be conceptualized as a 'formal authority' with legitimacy-seeking imperatives stemming from the political hegemony (both material and cultural) of member states and their institutions in the Euro-polity (Sbragia 1990). While claiming to be a parliament like any other, the EP must find its place in a democratic polity of a new kind: a 'demoi-cracy' that is young, weakly centred and culturally as well as linguistically plural (Nicolaidis 2004 ; Cheneval et al 2015 ). A key feature of EU democracy is that it is 'evolving on the basis of mainly nationally constituted demoi' (Cheneval et al. 2015, p.2) or 'community of others' (Weiler 1999, Nicolaïdis 2004, cited in Cheneval et al. 2015, p.2). This means that EP assertion, more than is the case in any other parliament or perhaps even in any other policy-making authority in the EU, must either rely on informal power-sharing mechanisms to coopt member states or, in Selznick’s words, mobilize the community for action.

Understanding the profound and continuing cultural relevance of the demoi is key, because it has two main implications. The first is that the EP will seek to compensate for the weakness of its electoral linkage to European societies by cultivating close ties to advocates of diffuse interests. The EP's long-standing need for institutional assertion, linked to the limited basis of its popular mandate (43\% turnout in each of the past two elections), has long been considered to make it a hospitable location for diffuse interests. Pollack observed that ' as the Community's only directly elected political organization,' the EP 'has acted not only as a competence-maximiser like the Commission, but also as a champion of the environment, consumers, women, and other diffuse but electorally popular causes.' (Pollack, 1997: 580-1). The elective affinities between diffuse interests and EP 
assertion have a lasting character since they are bound up with the legitimacy of this institution.

The second implications is that a basic imperative for the EP is to develop institutional autonomy in order to sustain long-standing ties to civil society organizations. Institutional autonomy may be understood as the capacity of the EP to 'formulate independent goals and development strategies' (Skocpol 1985). Given the technical complexity of EU policy-making, a key component of EP autonomy is the development of reliable and high-quality in-house knowledge. The point, however, is about institution-building, not just policy-making imperatives. In other words, it is not simply that knowledge is indispensable for the EP to perform its policy-making functions, but more importantly, that 'the institutionalization of public processes from promoting and applying economic knowledge is...connected to [institution] building' (Furner and Supple 1990, 31).

In the following section, we substantiate this alternative view of the EP as a demoi-cratic, legitimacy-seeking institution by providing summary evidence of enduring EP-NGO ties and developing endogenous knowledge capacities.

\section{NGO-friendly knowledge-building}

We illustrate the above arguments with reference to case studies. Developing a regulatory response to the financial crisis presented a notable opportunity in EP7 for the European Parliament to showcase its role as a guardian of diffuse interests. Thus, the Economic and Monetary Affairs committee of the EP (ECON) used the opportunity to successfully achieve its goals of a cap on bankers' bonuses in the 2013 Capital Requirements Regulation (CRR), sacrificing where necessary its positions in associated files on issues of lower saliency (House of Commons, 2017). Whilst the 
degree of saliency offers one established means to read the acts of legislatures, it can be extended to capture wider processes of norm diffusion in which the supply of information plays a key role. An example of the latter involves the Green member of the EP's negotiating team helping to sustainably fill gaps in information supply as a means to regulate banks through the establishment of Finance Watch by Green MEPs in 2011. Since its establishment this NGO has developed a staff complement of 13, funded by grants from the European Commission (50\%), and foundations and other sources (Finance Watch, 2017). It continues to need a variety of technical information and political intelligence, the satisfaction of which requires interaction with a wide variety of sources. The legislative team from ECON driving the file met with a wide variety of stakeholders, with MEP assistants covering the field and using the information they acquired in order to enhance their ability to establish independent positions (Greenwood \& Roederer-Rynning, 2014)). In current regulatory files following a similar pattern on issues of high saliency involving concentration of costs and diffusion of benefits, legislative teams have demonstrated a similar adeptness. Thus, in order to establish caps on mobile phone roaming charges, the assistant to the Rapporteur on one of the lead policy committees played a key role in selecting 25 stakeholder organisations to meet with from among a total of 60 requests, using as their criteria which organisations seemed to be in a position to provide information to help develop the regulatory position (Moreton-Burt, 2015).

The EP's increasing informational requirements are a powerful driver of recent internal reforms, principally involving the establishment of the Economic Governance Support Unit in 2012, and the European Parliament Research Service (EPRS) in 2013. 40 staff currently work in EPRS (EPRS, 2016), in a library, a Members’ Research Services Directorate, and an Impact Assessment Directorate, 
Accepted for publication in European Politics and Society, 2019

whose internal services are supplemented with outsourced commissioning, and which anticipates the need for such assessments to accompany EP amendments introduced relatively late into the legislative process. Whilst committees continue to receive regular technical briefings from the European Commission, members are now well equipped to form their own independent assessments. The EP's capacities to Committee Secretariats have experienced significant growth, with staff of the Directorate General for Internal Policies (DGIpol), responsible for servicing most of the key co-decision committees, increasing by 12\% between 2011 and 2012 (European Parliament, 2014c). Secretariat sizes of 20-30 for the 22 Standing Committees of the EP are now commonplace. Each member now receives funding for four assistants. Few national parliaments, with the clear exception of US Congress, enjoy access to knowledge and expertise on the scale enjoyed by the European Parliament.

A less visible source of information for MEPs are the policy advisors from the political groups of the European Parliament. There is no available scholarly analysis of these actors, but little doubt as to their central information role, as highlighted by Busby in an ethnographic write up of her seven month internship in the EP:

“Once an MEP becomes a rapporteur or shadow and becomes involved in the detailed work of a report, the first people they are likely to contact are the group co-ordinator, relevant group Policy Advisor, and committee secretariat Advisors” (Busby, 2013, p.104).

Political groups have allocations of policy advisors according to a formula centred on the number of MEPs attached to the group, ranging from three officials for a 
'busy' committee for each of the larger groups through to one advisor per three committees for the smallest (Corbett, Jacobs and Shackleton, 2011). Many are of sufficient longevity in post to enable them to develop substantial expertise, and, as described in the next section, have corresponding links with NGOs which share their outlook. MEPs assistants also often act as a direct point of contact between the member and lobby groups, fielding a substantial number of emails per day, and often meeting with such groups as a substitute for an otherwise busy member (Busby, 2013; Busby and Belkacem, 2013). These regular and routinized contacts enable them to acquire policy specific as well as political information from a diverse number of sources. Assistants may not be able to master the detail of every legislative clause in files which may extend to hundreds of pages, but work to the main policy goals of their MEPs, and sufficient to ensure that MEPs can steer the political course they seek from a file. Whilst assistants have a higher turnover than political group staff because they are at an earlier career stage, a familiar pathway is a subsequent move into positions with organisations involved in advocacy to political institutions. These young actors often come straight from higher education, often with activist experiences well suited to careers in politics. The café lined Place Lux, situated in front of the EP, on Thursday after work is an essential network venue where early career stagers in the 'Brussels bubble', where friendships from student days are refreshed in the new context of professional interactions, and introductions flourish. These networks form part of the knowledge circulation exchanges in which the EP is embedded, with little to suppose that information flows would become orientated towards producer interests as a result of new legislative powers in co-decision. 


\section{Reconsidering the EP's relationship with organized interests: Preliminary evidence from the NGOs}

Many claims regarding the declining status of NGOs with the EP reviewed earlier are centred on institutional changes within the EP itself. In this section we turn our attention to NGO themselves. We draw data from interviews with NGOs and social movements operating at EU level (14), bifurcated between those involved in crossparty intergroups (for reasons discussed below), and across eight of the major NGO 'families' at EU level as well as those operating across EP committee areas involving co-decision. In the EP, we conducted semi-structured interviews with a variety of personnel drawn from 16 of 22 legislative committees involved with co-decision, the EP political groups (Roederer-Rynning and Greenwood, 2015), and with senior staff from 11 NGOs with an EP liaison officer to the EP, or which acted as an NGO 'family' head. We take into account the comment of a reviewer that NGOs might tend to overestimate their influence in the EP and to downplay obstacles, but this is not our experience; if anything, we see a tendency to under-estimate one’s own influence and to over-estimate the influence of one's opponent. We supplemented this information with selected interviews in the Commission and Council (RoedererRynning \& Greenwood, 2017)). Finally, we supplement these insights with EU Transparency Register data on organizations holding access passes to the European Parliament. We use these data to explore: 1) how NGOs perceive the EP as a continuing venue for influence; 2) to what extent they identify co-decision practices (especially the trilogues) as detrimental to their engagement of the EP; and 3) how they engage the EP. If the political opportunity view is correct, we should see significant changes in NGO patterns of EP engagement, reflecting some perceptions that the EP has become a less permeable venue for influence. On the other hand, if 
Accepted for publication in European Politics and Society, 2019

the view of the EP as a demoi-cratic, legitimacy-seeking institution is correct, then we should see that NGOs continue to experience the EP as a receptive venue for influence, and that their pattern of EP engagement reflects factors internal to their development.

\section{NGO strategies of EP engagement}

A clear distinction can be drawn among NGOs as to the way they manage their relations with the European Parliament. One segment, typically concerned with demographic issues involving cross-party consensus such as age and disability, have institutionalized their relationship with the EP through a corresponding 'intergroup’. Whilst intergroups have no formal role in EP decision making, they are established in conformity with a set of EP regulatory rules (mainly for purposes of transparency and limiting their total number), providing an opportunity for cross-party, crosscommittee forums bringing together MEPs with common interests. Using this route, intergroups can provide a means of agenda-setting with EP committees, providing a highly attractive route into the EP for NGOs (interviews 1-4). Their number is restricted to 28. A less formal structure still involves the establishment of an interest group, which have no official EP status at all and there is no central record of them, but which perform similar functions to that of an intergroup. A lead NGO often provides a secretariat function for intergroups and interest groups to meet, to which the NGO assigns a post-holder to act as dedicated EP liaison officer. At the start of each EP term intergroups are established anew and NGOs campaign among MEPs and parties for their support, although some date back to the first EP term; one NGO saw them as providing 'a privileged relationship with the European Parliament' (interview 5). In this latter case, the intergroup provided not only a means of agenda- 
setting but also a campaign platform, in which the intergroup organizes public events in the European Parliament, numbering six in the 2013 European Year of Citizens. The pattern of engagement shows how the EP values participatory norms, and ultimately seeks legitimacy from its interaction with NGOs. An NGO servicing another long-time intergroup emphasized how 'the EP is our established best friend' (interview 6). The 18 Intergroups and Interest Groups in which EU NGOs play a key role are listed in Table 1:

\section{TABLE 1 HERE}

In NGOs without a corresponding intergroup/interest group, relations with the European Parliament are 'mainstreamed' in the daily work of their policy secretariats. Recent contributions to the literature have shown how MEP 'foes' are increasingly lobbied, in addition to 'friends' and (if different) the Rapporteur (Marshall, 2010; 2014). In a further nuance on the 'friends' theme, a characterisation was offered to us during the course of interviews which suggested that NGOs which need to lobby MEPs may have one ‘touch base’ meeting with their natural supporters (e.g. environmental protection NGOs with Green MEPs), then spend much of their time lobbying MEPs from the next most likely constituency (e.g. green NGOs with MEPs from the Socialists \& Democrats ${ }^{\mathrm{i}}$ ) (interview 8). Beyond legislative files, NGOs we interviewed reported the maintenance of long-term relationships with the President of the EP, the Conference of Presidents of Political Groups, with individual Committee Chairs, and in some cases with political group co-ordinators. NGOs use these established relationships with MEPs to work on EP own-initiative reports (an example provided in interviews involved a report on long-term care; interviews 6 and 7) and EP opinions (such as a report of the impact of the financial crisis on vulnerable groups; interview 9). These examples have been particularly significant for a large 
Accepted for publication in European Politics and Society, 2019

number of NGOs in the established family of social policy NGOs (the Social Platform), and from there to the family of health policy NGOs, whose lead organisation (European Public Health Alliance) currently hosts the 'family of families’ of NGOs, the Contact Group of Civil Society (interview 9). Our interviews with NGOs had also followed hard on the heels of inter-institutional negotiations over the EU Multi-Annual Budget Framework (2014-2020), where EU NGOs from education, culture, and social policy areas recounted tales of how they found crossparty support in the EP to restore budget lines removed by European Commission austerity inspired proposals to scale back EU spending (interviews 10, 11, 12).

A surprisingly understated factor in the literature on the EP is the way in which its electoral cycle provides NGOs with opportunities for advocacy and campaigning. This may have been based on an assumption that all EU politics is elitist (see, for instance, Saurugger, 2008) and that links between federated EU NGOs and civil society are largely symbolic. The NGOs we interviewed were actively campaigning among election candidates to secure pledges on policy commitments, using their websites to list responses (or otherwise) from candidates. One NGO told us how the advisors from all the political groups had been consulted during the preparation of these pledges (interview 13).

A political group advisor we interviewed (interview 14) had been active in social movements during the defeat by the EP of the proposal for a software patent Directive in $2005^{\mathrm{ii}}$. This linkage between diffuse interests and political group advisors was highlighted in the comments of another NGO:

"When we have prepared amendments it is essential for us to have contact with political advisors; MEPs follow instructions from party groups, so you should 
Accepted for publication in European Politics and Society, 2019

never underestimate the influence of the political advisor, who often has substantial expertise” (interview 15).

Another NGO identified how both political advisors and assistants provided her best contacts (interview 16), while another e-NGO commented that “you need excellent relationships with the Assistants, and you have to add value there” (interview 17). These formal and informal exchanges strengthen the independent basis for EP policy action.

\section{Resources}

Whilst the EU Transparency Register carries some limitations of data quality, the information it provides about the main players lobbying at EU level has shown a steady improvement over time, partly due to the activist role of NGO watchdogs. Despite perceptions to the contrary, the differences in resources deployed for lobbying related activities between producer and diffuse interests are relatively narrow (citation 4), largely due to an extensive system of funding for NGOs. The 'hotspot' of premium property rental costs in Brussels is currently the district adjacent to the EP surrounding the Square de Meeûs (SdM) (Politico, 2015); a clutch of 'NGO houses,' based on a model of ethical funding streams providing property and shared backoffice facilities, offer a large number of NGOs with the means to locate themselves alongside the best resourced business related advocates ${ }^{\mathrm{iii}}$. In terms of specific resources devoted to the EP, the Transparency Register provides data about passholders, which provides an indication of levels of professional engagement. Access to an EP pass provides a substantial incentive for organisations to sign up to the Transparency Register. The scheme provides twelve months accreditation for organisations to obtain a one-day pass to the EP on demand via a dedicated desk, with largely unrestricted roaming thereafter, and which provides substantial opportunities 
Accepted for publication in European Politics and Society, 2019

to network with EP staff and staff of MEPs as well as the members themselves. The currency of political consultancies is information, and thus it is unsurprising they should be the highest average pass-holders of all categories of interest on the Transparency Register (3.6 per organisation). But of significance is that the 360 NGOs (category III of the register) with a pass to the EP premises hold an average of 2.8 passes per organisation, compared to an average of 2.6 for the 850 producer organisations (mainly companies and business associations) in category II of the register (Table 2):

TABLE 2 HERE

Table 2 demonstrates broad equivalence between category II and III passholders across a number of variables, including the proportion of organisations holding a pass (whether an organisation is based inside Belgium or outside), as well as the number of passes held. Table 3 shows the distribution of pass-holders in category III of the register, while Table 4 identifies the organisations in category III with the highest number of passes, where the active positions of global NGOs with EU policy offices, as well as the European Consumers' Organisation (BEUC) is clear.

TABLE 3 HERE

TABLE 4 HERE

A relatively neglected issue in the literature on the EP committee system involves the largely unseen work of sub-committees, and which have been used a 
means of agenda-setting issues for a dense landscape of health related NGOs (Greer, 2009) active at EU level. In our interviews, we also found evidence that health related NGOs were using this route, while there was a tendency in EP7 for committees working in core producer fields, such as ECON, to resist the use of sub- committees as a means of making their work more visible (interview 18). We did not encounter during the course of our interviews with either NGOs or with the ENVI secretariat any evidence that the changes to the EP Committee system introduced by the Hughes procedure had resulted in a dilution of the ability of ENVI to champion diffuse causes. The mechanism is a two-way street, with ENVI issuing twelve challenges of its own during the course of EP7 (European Parliament, 2014b). As one interviewee from an environmental NGO established at EU level explained:

"the more committees you have working intensively on an issue - even as an opinion committee - so you will get more amendments generated, which the lead committee have to consider. So the result is pluralism” (interview 19).

In sum, neither Transparency Register access pass data nor our interviews provide evidence that the EP's enhanced powers have come at a cost to NGOs. Rather, they demonstrate a picture of the EP as valuing participatory norm, extending to the way in which the EU primarily seeks legitimacy.

\section{Trilogues}

The growing extent of trilogues as a legislative mechanism has resulted in participation from the Parliament side becoming increasingly formalized over time through Rules of Procedure (69) to provide for checks and balances. Negotiating mandates are approved either at Committee level or in Plenary of the EP, and 
negotiators report back regularly to Committees and always to the Members of committees who serve as political group co-ordinators, with the final agreement subject to approval at Committee and then Plenary. These have been accompanied by cross-committee norms in which Committee Chairs chair trilogue meetings as a means to enforce committee positions (citation 1). These arrangements therefore strengthen the EP's capacity for institutional assertion linked to champion public interest positions. Whilst access to information from trilogues requires diffuse interests to be organized, we found little evidence among the NGOs we interviewed that the secluded nature of trilogues present difficulties for them. One NGO EP liaison officer sought to convey the sufficiency of his own antennae with the comment that "if you have the frequency you can tune in to it" (interview 20), while another remarked that 'as soon as you have a trilogue half of Brussels knows what goes on' (interview 21). NGOs generally reported the EP as their information source from trilogues, sometimes proposed amendments which EP negotiators used in trilogues (interview 22). One commented on how MEPs assistants would send him text messages informing him about the course of negotiations during the trilogue meeting itself (interview 23), while others reported returning information by this means to EP negotiators during Trilogue meetings (interview 24). Where necessary, EP negotiators use NGOs as a means to obtain a reaction (interview 25), or as a means of exerting leverage on the Council (interview 26), and sometimes as a route to the media. In the development policy field, we also found evidence of member state permanent representations using NGOs as a means of influencing the position of other member states in the Council (interview 27). Beyond political purposes, we found evidence of engagement with technical trilogues by NGOs through contact with political group 
Accepted for publication in European Politics and Society, 2019

staff (interview 20). These insights provide evidence of the two-way dialogue in which NGOs are engage with trilogues.

\section{Concluding Discussion}

In this article, we begin revisiting, in the light of contemporary evidence, an influential claim in the literature on EU policy making that the EP is a highly receptive venue for diffuse interests. This claim has recently come under pressure from explanations related to the shift from consultation to co-decision, and political factors related to the internal political opportunity structure in the EP. As this literature is rapidly developing, we have shown that a political opportunity structure framework provides a conceptual umbrella to highlight the common focus of these claims on structural-institutional constraints of NGO engagement, while recognizing their specific contribution for understanding evolving EP preferences, the institutional rules of the game under co-decision, and specific versus general opportunities. The evidence we provide nuances the literature on the EP. It is difficult to trace the shift to co-decision to a systematic change in EP behaviour vis-à-vis diffuse interests. It seems fruitless to look for a macro-level across-the-board effect of co-decision. Rather, the links between the EP and NGOs are variegated and much more contextsensitive. As Rasmussen (2015) found, the continuing ability of the traditional EP/NGO nexus to prevail is dependent on a series of much more specific variables, such as: the extent to which business is unified on a given policy option; the level of committee support; the level of member state support; and the policy issue type (Rasmussen, 2015). These findings resonate with emphasis on the significance of framing, and issue saliency, in explaining variation in legislative outcomes at EU level (Klüver, Braun \& Beyers, 2015). They suggest that the concept of political 
opportunity structure can only be fruitful if it is operationalized at a much finer degree of detail.

On the EP side, contrary to common expectations that increased legislative competence might reduce the EP's receptiveness to diffuse interests, we found that the EP's enduring desire for institutional assertion goes hand-in-hand with a commitment to pluralisation and the promotion of diffuse interests. Some highly salient issues in complex, and traditionally producer-dominated policy fields have provided an opportunity for the EP to demonstrate it is still the champion of diffuse interests. In particular, we have shown how the EP has developed knowledge capacities to act as an autonomous actor. The EP has become a formidably wellresourced actor, probably only second to the US Congress in terms of access to economic and policy knowledge. The assumed poor capacity of EP committee secretariats has been remedied, while the formation of the European Parliament Research Service in 2013 provides the means to undertake impact assessments through a mixture of in-house and outsourced resources. These developments postdate a number of earlier contributions to the debate about the supposedly poor information capacity of the EP to keep pace with its enhanced powers. Moreover, vigorous networks based around MEPs assistants, as well as policy advisors of party groups provide evidence of the robustness of ties between MEPs and well institutionalized NGOs as diffuse interest advocates. The distributional effects of regulatory proposals ensure contestation and a continued supply of information which helps to nurture the institutional autonomy of the EP.

On the NGOs’ side, data from the Transparency Register about EP pass holders helps to reinforce a picture of a population of NGOs established at EU level which is sufficiently well resourced to be able to engage with the EP at a level of 
depth. We do not find much evidence that changes in the decision-making procedure have made the EP a less receptive venue for influence. We also identified how NGOs work with the electoral cycle of the EP to their advantage in ways which would be less suitable for many business related organisations, such as public campaigning aimed at securing pledges from MEPs. We have found that a key driver which differentiates the way in which NGOs work with the EP, with a core group of NGOs primarily (but not exclusively) centred around the issue-specific features of their work. While NGOs in the field of demographic politics work intensively through intergroups, and have a dedicated EP liaison officer, other NGOs ‘mainstream' EP relations in the work of their policy officers. Issues like aging or disability, and health related policy fields, lend themselves particularly well to the development of crossparty consensus given their cross-cutting nature. Finally, when lobbying is directed elsewhere than the EP, this sometimes reflects a logic of 'next best' friend—-taking the EP as 'the best friend' as a given.

These insights nuance the literature on the EP while supporting well- grounded accounts of the generally beneficial effect of EP actions for some types of NGOs, as advocates of diffuse interests (Bernhagen, Dür \& Marshall, 2015). On highly salient issues, both the EP and NGOs continue to take up strong public goods orientated positions, and where citizen mobilisation comes in advance of NGO activism there are stronger incentives for EP alignment. They also provide preliminary support for the view of the EP as demoi-cratic, legitimacy-seeking institution. In this article, we have outlined a "demoi-cratic" perspective on this issue. Our take is that viewing the EP as a legitimacy seeking institution suggests a different outlook for EP-NGO relations, as the EP, acting upon accepted standards of legitimacy, will seek to develop institutional autonomy, including internal economic and social knowledge, 
Accepted for publication in European Politics and Society, 2019

and valuing participatory norms. These are only preliminary findings. Further research must flesh out the demoi-cratic framework and its implications. For normative reasons, and given the multi-level character of the EU, we should expect the EP to continue to cultivate ties to NGOs and develop the knowledge capacities required to establish an autonomous policy space. 
Accepted for publication in European Politics and Society, 2019

\section{References}

Bernhagen P, Dür A, and Marshall D. (2015) 'Information or Context: what accounts for positional proximity between the European Commission and lobbyists?' Journal of European Public Policy, 22, 4:570-587.

Bouwen, P. (2004) 'The Logic of Access to the European Parliament', Journal of Common Market Studies, 42(3): 473-495.

Bouwen, P and Mccown, M (2007) 'Lobbying versus litigation: political and legal strategies of interest representation in the European Union', Journal of European Public Policy, 14:3, 422-443.

Bunyan, T. (2007) Secret Trilogues and the Democratic Deficit, Statewatch analyses 64, http://www.statewatch.org/analyses/no-64-secret-trilogues.pdf (accessed 2 December 2016).

Burns, C. and Carter, N. (2010) 'Is Co-decision Good for the Environment? An analysis of the European Parliament’s Green Credentials’, Political Studies, 58: 123143.

Burns C., Carter N., Davies G. and Worsfold N., (2013) 'Still saving the earth? The European Parliament's environmental record', Environmental Politics, 22(6): 935954. 
Accepted for publication in European Politics and Society, 2019

Burson Marsteller (2009) A Guide to Effective Lobbying in Europe

http://www.oursocialmedia.com/wp-content/uploads/effective-

lobbying_light_07102009.pdf (accessed 2 December 2016).

Busby, A. (2013) ' 'Normal Parliament’: Exploring the Organization of Everyday

Political Life in an MEPs office', Journal of Contemporary European Research, 9(1):

94-115.

Busby, A. and Belkacem, A. (2013) '”Coping with the information overload”: an exploration of assistants' backstage role in the everyday practice of European Parliament politics, European Integration online Papers (EiOP) 17: 1-28.

Cheneval, F. and Schimmelfennig, F. (2013) 'The Case for Demoicracy in the European Union', Journal of Common Market Studies 51(2): 334-50.

Cheneval, F., Lavenex, S. and Schimmelfennig, F. (2015) 'Demoi-cracy in the European Union: principles, institutions, policies', Journal of European Public Policy, 22(1): 1-18.

Corbett R, Jacobs .F and Shackleton M. (2011, $8^{\text {th }}$ edtn.) The European Parliament (London: John Harper).

Dür, A. and de Bièvre, D. (2007) 'The question of interest group influence', Journal of Public Policy, 27(1): 1-12. 
Accepted for publication in European Politics and Society, 2019

Dür, A. and Mateo, G. (2014) ‘Public Opinion and Interest Group Influence’, Journal of European Public Policy, 21(8): 1199-1217.

EurActiv (2015) Secretive ‘Trialogue talks to agree EU law face investigation’, http://www.euractiv.com/sections/eu-priorities-2020/secretive-trialogue-talks-agreeeu-law-face-investigation-313936

(accessed on 2 December 2016).

EurActiv (2017) Balancing Secrecy and Openness, the EU Strives for Transparency, EurActiv, https://www.euractiv.com/section/politics/news/balancing-secrecy-andopenness-the-eu-strives-for-transparency/ (accessed on 1 December 2017

European Economic and Social Committee (2017) Investigation of informal trilogue negotiations since the Lisbon Treaty - Added value, lack of transparency and possible democratic deficit, contract No. CES/CSS/13/2016 23284, http://www.eesc.europa.eu/en/ourwork/publications-other-work/publications/investigation-informal-trilogue-negotiationslisbon-treaty-added-value-lack-transparency-and-possible-democratic-deficit (accessed on 1 December 2017)

European Parliament (2014a) Activity Report on Co-decision and Conciliation, $7^{\text {th }}$ Parliamentary Term, http://www.europarl.europa.eu/code/information/activity_reports/activity_report_200 9_2014_en.pdf (accessed on 2 December 2016).

European Parliament (2014b) Committee Statistical Report: $7^{\text {th }}$ Legislature, DGIpol Unit for Legislative Coordination, 
Accepted for publication in European Politics and Society, 2019

http://www.europarl.europa.eu/code/about/starreport_en.pdf (accessed on 2 December 2016).

European Parliament DGIpol (2014c) Annual Activity Report, http://www.europarl.europa.eu/document/activities/cont/201411/20141113ATT93202 /20141113ATT93202EN.pdf (accessed on 2 December 2016).

European Parliamentary Research Service (EPRS) (2016) The work of EPRS: the first two years: 2014 and 2015 http://www.europarl.europa.eu/EPRS/Work_of_EPRS_2014-15_2years.pdf (Accessed 2 December 2016).

Finance Watch (2017) Annual Report 2016 http://www.finance-watch.org/aboutus/governance-and-funding (accessed 1 December 2017).

Furner, M. and Supple, B. (1990) 'Ideas, Institution and State' in the United States and Britain: an introduction, in Mary Furner and Barry Supple The State and Economic Knowledge: American and British Experiences. New York: Cambridge University Press, 1-39.

Gehlen, C (2006) 'Lobbying in Brussels: the EU Directive on the Patentability of Computer Implemented Inventions’ (Fontainebleu: INSEAD), case 11/2006-5375. 
Accepted for publication in European Politics and Society, 2019

Greenwood, J (2017) Interest Representation in the European Union (Basingstoke: Palgrave Macmillan).

Greenwood, J \& Roederer-Rynning, C (2014) "The 'Europeanization' of the Basel Process: Financial Harmonization between Globalization and Parliamentarization," Regulation \& Governance, 9, 4, 335-338.

Greer, S. (2009) The Politics of EU Health Policies. Buckingham: Open University Press.

House of Commons (2017) Letter from European Scrutiny Committee to the European Ombudsman, 9 March 2016, https://www.ombudsman.europa.eu/en/cases/correspondence.faces/en/67634/html.boo kmark (accessed on 1 December 2017).

Imig, D and Tarrow, S (2001) (eds.) Contentious Europeans: protest \& politics in an integrating Europe. Boulder: Rowman \& Littlefield.

International New York Times (2014) 'E.U. chided for lack of openness’ 24 April 2014, http://news-business.vlex.com/vid/chided-corruption-growing-distrust$\underline{507432674}$ (accessed 16 June 2014).

Joachim, J. and Locher, B. (2009) (eds.) Transnational Activism in the UN and the EU. London: Routledge. 
Accepted for publication in European Politics and Society, 2019

Judge, D. (1992) 'Predestined to Save the Earth: the Environmental Committee of the European Parliament', Environmental Politics, 1: 186-212.

Judge, D and Earnshaw, D (2011) ‘Relais actors’ and co-decision first reading agreements in the European Parliament: the case of the advanced therapies regulation, Journal of European Public Policy, 18, 1, 53-71.

Junk, W M (2015) 'Two logics of NGO advocacy: understanding inside and outside lobbying on EU environmental policies’, Journal of European Public Policy, 23: 2, 236-54

Klüver H, Braun C \& Beyers J (2015) Legislative Lobbying in Context: towards a conceptual framework of interest group lobbying in the European Union, 22,4:447461.

Kohler-Koch, B. (1998) 'Organized Interests in the EU and the European Parliament', in P-H Claeys, C Gobin, I Smets and P Winand (eds.) Lobbyisme, Pluralisme et Intégration Européenne. Brussels: European Interuniversity Press, 126-158.

Marks, G and McAdam D (1996) 'Social Movements and the Changing Structure of Political Opportunity in the European Union’, West European Politics, 19(2): 249278. 
Accepted for publication in European Politics and Society, 2019

Marshall, D. (2010) 'Who to lobby and when: Institutional determinants of interest group strategies in European Parliament committees’, European Union Politics, 11(4): 553-575.

Marshall, D. (2012) 'Do rapporteurs receive independent expert policy advice? Indirect lobbying via the European Parliament's committee secretariat', Journal of European Public Policy, 19(9): 1377-1995.

Marshall, D. (2014) ‘Explaining Interest Group Interactions with Party Group Members in the European Parliament: Dominant Party Groups and Coalition Formation', Journal of Common Market Studies, 53, 2:311-329.

Moreton Burt, J (2015) 'Let the people roam free: Why interest groups lobbying the European Parliament on the EU's mobile roaming legislation had access but not influence',

Nicolaïdis, K. (2004) ‘The New Constitution as European “Demoi-cracy”?’ Critical Review of International Social and Political Philosophy 7(1): 76-93.

Palmeri, T. (2015) The Brussels Gucci gulch, Politico, http://www.politico.eu/article/brussels-real-estate-lobbying-parliament/ 20 May 2015, accessed on 2 December 2016.

Pollack, M. (1997) 'Representing diffuse interests in EC policymaking', Journal of European Public Policy, 4(4): 572-590. 
Accepted for publication in European Politics and Society, 2019

Rasmussen, M. (2012) 'Is the European Parliament still a policy champion for environmental interests?’ Interest Groups \& Advocacy, 1(2): 239-259.

Rasmussen, M. (2014) 'The Battle for Influence: the Politics of Business Lobbying in the European Parliament,' Journal of Common Market Studies, 53, 2: 365-382.

Ripoll Servent, A. and Mackenzie, A. (2011) 'Is the EP Still a Data Protection Champion? The Case of SWIFT', Perspectives on European Politics and Society, 12(4): 390-406.

Roederer-Rynning, C (2018) 'Passage to Bicameralism: Lisbon's 'Ordinary Legislative Procedure' at Ten', Comparative European Politics,

Roederer-Rynning, C and Greenwood, J (2015) 'The Culture of Trilogues', Journal of European Public Policy, 22, 8: 1148-1165.

Roederer-Rynning, C and Greenwood, J (2017) The European Parliament as a developing legislature: coming of age in trilogues? Journal of European Public Policy, 24, 5: 735-754.

Saurugger, S. (2008) 'Interest Groups and Democracy in the European Union’, West European Politics, 31(6): 1274-91. 
Accepted for publication in European Politics and Society, 2019

Skocpol, T. (1985). 'Bringing the state back in: strategies of analysis in current research', in P. Evans, D. Rueschemeyer and T. Skocpol (eds.), Bringing the State Back In. Cambridge: Cambridge University Press, 3-43.

Smith, M. (2008) 'All Access Points are Not Created Equal: Explaining the Fate of Diffuse Interests in the EU', British Journal of Politics \& International Relations, 10: 64-83.

Steffek, J (2013) 'Explaining Cooperation between IGOs and NGOs - Push Factors, Pull Factors, and the Policy Cycle’, Review of International Studies 39(4): 993-1013.

Tarrow, S (1992) ‘Mentalities, Political Cultures and Collective Action Frames’ in Aldon Morris and Carol McLurg Mueller (eds.) Frontiers in Social Movement Theory. New Haven: Yale University Press, 174-202. 
Accepted for publication in European Politics and Society, 2019

\section{Interviews}

Interview 1 with an NGO established at EU level, Brussels, 20.5.2014

Interview 2 with an NGO established at EU level, Brussels, 19.5.2014

Interview 3 with an NGO established at EU level, Brussels, 10.9.2014

Interview 4 with an NGO established at EU level, Brussels, 12.9.2014

Interview 5 with an NGO established at EU level, Brussels, 3.10.2014

Interview 6 with an e-NGO established at EU level, Brussels, 28.4.2014

Interview 7 as per interview 5.

Interview 8 with an e-NGO established at EU level, Brussels, 8.9.2014

Interview 9 as per interview 5.

Interview 10 with an NGO established at EU level, Brussels, 21.5.2014

Interview 11 as per interview 10.

Interview 12 with an NGO established at EU level, Brussels, 21.5.2014

Interview 13 - with an NGO established at EU level, Brussels, 21.5.2014

Interview 14 with an advisor to a political group in the EP, 8.1.2015

Interview 15 as per interview 13.

Interview 16 as per interview 8.

Interview 17 as per interview 6.

Interview 18 with a Chair of a European Parliament Committee, UK, 7.7.2014

Interview 19 as per interview 6.

Interview 20 as per interview 6.

Interview 21 as per interview 8.

Interview 22 as per interview 8.

Interview 23 as per interview 8. 
Accepted for publication in European Politics and Society, 2019

Interview 24 as per interview 6.

Interview 25 as per interview 17.

Interview 26 as per interview 8.

Interview 27 with an NGO established at EU level, Brussels, 6.2.2015 
Accepted for publication in European Politics and Society, 2019

Table 1: Intergroups and Interest Groups with NGO Secretariats, 2016

\begin{tabular}{|c|c|c|c|c|}
\hline $\begin{array}{l}\text { Intergroup (or } \\
\text { interest group) } \\
\text { name }\end{array}$ & $\begin{array}{l}\text { Status } \\
\text { IP=Intergr } \\
\text { oup, } \\
\text { IG = } \\
\text { Interest } \\
\text { Group }\end{array}$ & $\begin{array}{l}\text { NGO providing } \\
\text { secretariat }\end{array}$ & $\begin{array}{l}\text { Transpare } \\
\text { ncy } \\
\text { Register } \\
\text { staff } \\
\text { declaration }\end{array}$ & $\begin{array}{l}\text { N. EP } \\
\text { access } \\
\text { passes }\end{array}$ \\
\hline $\begin{array}{l}\text { Active Ageing, } \\
\text { Intergenerational } \\
\text { Solidarity and } \\
\text { Family policies }\end{array}$ & IP & AGE Platform Europe & 14 & 7 \\
\hline Allergy \& Asthma & IG & $\begin{array}{l}\text { European Federation } \\
\text { of Allergy \& Airways } \\
\text { Diseases Patients } \\
\text { Associations }\end{array}$ & No entry & \\
\hline $\begin{array}{l}\text { Anti-Racism and } \\
\text { Diversity }\end{array}$ & IP & $\begin{array}{l}\text { European Network } \\
\text { Against Racism } \\
\text { (ENAR) }\end{array}$ & 9 & 4 \\
\hline $\begin{array}{l}\text { Brain, Mind \& } \\
\text { Pain }\end{array}$ & IG & $\begin{array}{l}\text { European Federation } \\
\text { of Neurological } \\
\text { Associations/Pain } \\
\text { Alliance Europe }\end{array}$ & $1 / 6$ & $5 / 7$ \\
\hline Carers & IG & Eurocarers & 4 & 3 \\
\hline Disability & IP & $\begin{array}{l}\text { European Disability } \\
\text { Forum (EDF) }\end{array}$ & 12 & 6 \\
\hline $\begin{array}{l}\text { Extreme Poverty } \\
\text { and Human Rights }\end{array}$ & IP & ATD Quart Monde & 3 & 0 \\
\hline $\begin{array}{l}\text { European Patients } \\
\text { Rights \& Cross- } \\
\text { Border Healthcare }\end{array}$ & IG & $\begin{array}{l}\text { Active Citizenship } \\
\text { Network }\end{array}$ & No entry & \\
\hline $\begin{array}{l}\text { Innovation in } \\
\text { Health \& Social } \\
\text { Care } \\
\end{array}$ & IG & Health First Europe & 2 & 0 \\
\hline $\begin{array}{l}\text { Lesbian, Gay, } \\
\text { Bisexual and } \\
\text { Transgender }\end{array}$ & IP & $\begin{array}{l}\text { The European Region } \\
\text { of the International } \\
\text { Lesbian, Gay, } \\
\text { Bisexual, Trans and } \\
\text { Intersex Association }\end{array}$ & 4.5 & 1 \\
\hline $\begin{array}{l}\text { Maternal \& Neo- } \\
\text { natal health }\end{array}$ & IG & $\begin{array}{l}\text { European Federation } \\
\text { for the Care of } \\
\text { Newborn Infants }\end{array}$ & No entry & \\
\hline
\end{tabular}


Accepted for publication in European Politics and Society, 2019

\begin{tabular}{|l|l|l|l|l|}
\hline $\begin{array}{l}\text { Mental Health, } \\
\text { Well Being \& } \\
\text { Brain Disorder }\end{array}$ & IG & $\begin{array}{l}\text { Global Alliance of } \\
\text { Mental Illness } \\
\text { Advocacy Network }\end{array}$ & 1 & 0 \\
\hline $\begin{array}{l}\text { MEPs against } \\
\text { Cancer }\end{array}$ & IG & $\begin{array}{l}\text { Association of } \\
\text { European Cancer } \\
\text { Leagues }\end{array}$ & 6 & 6 \\
\hline MEP Heart Group & IG & $\begin{array}{l}\text { European Heart } \\
\text { Network/European } \\
\text { Society of Cardiology }\end{array}$ & $4 / 3$ & $3 / 1$ \\
\hline $\begin{array}{l}\text { Patient Access to } \\
\text { Health Care }\end{array}$ & IG & $\begin{array}{l}\text { Patient Access } \\
\text { Partnership }\end{array}$ & No entry & 1 \\
\hline $\begin{array}{l}\text { Social Economy, } \\
\text { social economy } \\
\text { enterprises, social } \\
\text { entrepreneurship } \\
\text { and third sector }\end{array}$ & IP & $\begin{array}{l}\text { Social Economy } \\
\text { Europe network }\end{array}$ & 3 & 7 \\
\hline $\begin{array}{l}\text { Welfare and } \\
\text { Conservation of } \\
\text { Animals }\end{array}$ & IP & $\begin{array}{l}\text { Eurogroup for } \\
\text { Animals }\end{array}$ & 5 & 4 \\
\hline $\begin{array}{l}\text { Youth issues } \\
\text { Sources: European }\end{array}$ & IP & $\begin{array}{l}\text { European Youth } \\
\text { Forum }\end{array}$ & 15 & 7 \\
\hline
\end{tabular}

Sources: European Parliament intergroup webpages; Transparency Register; NGO websites. 
Table 2: Transparency Register pass-holders to the European Parliament ${ }^{3}$

\begin{tabular}{|c|c|c|c|c|c|c|c|c|c|c|}
\hline Row Labels & $\begin{array}{l}\text { ALL } \\
\text { organisations }\end{array}$ & $\begin{array}{l}\text { How many with } \\
\text { EP pass }\end{array}$ & $\begin{array}{l}\% \text { of } \\
\text { organisations } \\
\text { having any } \\
\text { pass }\end{array}$ & $\begin{array}{l}\text { Average } \\
\text { passes } \\
\text { per } \\
\text { organisati } \\
\text { on }\end{array}$ & $\begin{array}{l}\text { Organisati } \\
\text { ons in } \\
\text { Belgium } \\
\end{array}$ & $\begin{array}{l}\% \text { of all } \\
\text { organisati } \\
\text { i ons that } \\
\text { are in } \\
\text { Belgium }\end{array}$ & $\begin{array}{l}\text { Belgium } \\
\text { organisati } \\
\text { ons with } \\
\text { EP pass }\end{array}$ & $\begin{array}{l}\% \text { of } \\
\text { organisati } \\
\text { ons with } \\
\text { EP Pass } \\
\text { that are in } \\
\text { Belgium }\end{array}$ & $\begin{array}{l}\text { \% of Belgian } \\
\text { organisations } \\
\text { having any pass }\end{array}$ & $\begin{array}{l}\text { Average } \\
\text { passes per } \\
\text { organisatio } \\
\mathrm{n} \text { Belgium }\end{array}$ \\
\hline I - Professional consultancies/law firms/self-employed consultants & 793 & 3211 & $127 \%$ & 3.6 & 318 & $340 \%$ & 162 & $2 \quad 77 \%$ & $51 \%$ & 4.2 \\
\hline Law firms & 72 & 9 & $13 \%$ & 1.4 & 25 & $35 \%$ & 5 & $56 \%$ & $20 \%$ & 1.4 \\
\hline Professional consultancies & 494 & 153 & $31 \%$ & 4.5 & 209 & $42 \%$ & 123 & $80 \%$ & $59 \%$ & 5.2 \\
\hline Self-employed consultants & 227 & 49 & $22 \%$ & 1.2 & 84 & $37 \%$ & 34 & $69 \%$ & $40 \%$ & 1.1 \\
\hline II - In-house lobbyists and trade/professional associations & 3272 & 850 & $26 \%$ & 2.6 & 1409 & $43 \%$ & 698 & $82 \%$ & $50 \%$ & 2.8 \\
\hline Companies \& groups & 896 & 305 & $34 \%$ & 2.5 & 357 & $40 \%$ & 230 & $75 \%$ & $64 \%$ & 2.8 \\
\hline Other similar organisations & 222 & 52 & $23 \%$ & 2.8 & 91 & $41 \%$ & 48 & $92 \%$ & $53 \%$ & 2.9 \\
\hline Trade unions & 139 & 27 & $19 \%$ & 2.2 & 45 & $32 \%$ & 22 & $81 \%$ & $49 \%$ & 2.5 \\
\hline Trade, business \& professional associations & 2015 & 466 & $23 \%$ & 2.6 & 916 & $45 \%$ & 398 & $85 \%$ & $43 \%$ & 2.8 \\
\hline III - Non-governmental organisations & 1649 & 360 & $22 \%$ & 2.8 & 590 & $36 \%$ & 280 & $78 \%$ & $47 \%$ & 3.0 \\
\hline Non-governmental organisations, platforms and networks and similar & 1649 & 360 & $22 \%$ & 2.8 & 590 & $36 \%$ & 280 & $78 \%$ & $47 \%$ & 3.0 \\
\hline IV - Think tanks, research and academic institutions & 466 & 61 & $13 \%$ & 2.0 & 130 & $28 \%$ & 48 & $79 \%$ & $37 \%$ & 2.1 \\
\hline Academic institutions & 129 & 10 & $8 \%$ & 1.7 & 19 & $15 \%$ & 7 & $70 \%$ & $37 \%$ & 2.0 \\
\hline Think tanks and research institutions & 337 & 51 & $15 \%$ & 2.1 & 111 & $33 \%$ & 41 & $80 \%$ & $37 \%$ & 2.1 \\
\hline V - Organisations representing churches and religious communities & 39 & 16 & $41 \%$ & 2.4 & 19 & $49 \%$ & 14 & $88 \%$ & $74 \%$ & 2.5 \\
\hline Organisations representing churches and religious communities & 39 & 16 & $41 \%$ & 2.4 & 19 & $49 \%$ & 14 & $88 \%$ & $74 \%$ & 2.5 \\
\hline VI - Organisations representing local, regional and municipal authorities & 299 & 54 & $18 \%$ & 3.9 & 133 & $44 \%$ & 40 & $74 \%$ & $30 \%$ & 2.5 \\
\hline Local, regional and municipal authorities (at sub-national level) & 128 & 23 & $18 \%$ & 3.6 & 71 & $55 \%$ & 17 & $74 \%$ & $24 \%$ & 3.9 \\
\hline Other public or mixed entities, etc. & 171 & 31 & $18 \%$ & 2.6 & 62 & $36 \%$ & 23 & $74 \%$ & $37 \%$ & 1.5 \\
\hline Grand Total & 6518 & 1552 & $24 \%$ & 2.8 & 2599 & $40 \%$ & 1242 & $80 \%$ & $48 \%$ & 3.0 \\
\hline
\end{tabular}

${ }^{3}$ We are grateful to J oanna Dreger for compilation of this table. 
Accepted for publication in European Politics and Society, 2019 
Table 3: Distribution of pass-holders in

Transparency Register Category III ${ }^{\text {iv }}$

\begin{tabular}{|l|l|}
\hline Number of passes & Distribution \\
\hline 1 & 135 \\
\hline 2 & 78 \\
\hline 3 & 54 \\
\hline 4 & 39 \\
\hline 5 & 17 \\
\hline 6 or more & 37 \\
\hline
\end{tabular}

Source: Transparency Register data, own analysis, 2018

Table 4: Top EP pass-holders: Transparency Register Category III

\begin{tabular}{|l|l|}
\hline Organisation & Number of passes \\
\hline $\begin{array}{l}\text { BEUC (European Consumers } \\
\text { Organisation) }\end{array}$ & 22 \\
\hline $\begin{array}{l}\text { Global Network for Rights and } \\
\text { Development }\end{array}$ & 15 \\
\hline German Consumers Association & 14 \\
\hline Greenpeace European Unit & 12 \\
\hline $\begin{array}{l}\text { Amnesty International European } \\
\text { institutions office }\end{array}$ & 11 \\
\hline European Women's Lobby & 11 \\
\hline ATHENA EULOGOS & 9 \\
\hline $\begin{array}{l}\text { Transparency International Liaison Office } \\
\text { to the EU }\end{array}$ & 9 \\
\hline
\end{tabular}

Source: Transparency Register data, own analysis, 2018 
${ }^{i}$ Group of the Progressive Alliance of Socialists and Democrats in the European Parliament. ii the European Commission proposal for a Directive on the Patentability of Computer Implemented Inventions 2002/0047 (COD) of 20 February 2002

iii Examples include SdM 18; Rue de l'Industrie 10; Rue d'Edimbourg 26.

iv 'NGOs, platforms and networks and similar.' 